\title{
A parlagfü okozta légzőszervi allergiás megbetegedések előfordulása Magyarországon
}

\author{
Márk Zsuzsa dr. ${ }^{1}$ - Bikov András dr. ${ }^{2,3}$. Gálffy Gabriella dr. ${ }^{2}$ \\ ${ }^{1}$ Tüdőgyógyintézet, Törökbálint \\ ${ }^{2}$ Semmelweis Egyetem, Általános Orvostudományi Kar, Pulmonológiai Klinika, Budapest \\ ${ }^{3}$ Bolyai-ösztöndíjas
}

\begin{abstract}
Bevezetés: A szerzők a parlagfú-allergiások számának becslésére a 18 év feletti lakosok körében végeztek országos, reprezentatív, kérdőives felmérést. Célkitüzés: Az elsődleges cél a tünetekkel élő parlagfü-allergiások felkutatása, a másodlagos cél a parlagfü-allergiások tüneteinek, kivizsgálásának, gyógyszerfogyasztási szokásainak a feltérképezése volt. Módszer: A szerző́k az általuk összeállított kérdőívvel 1000 lakost kerestek meg. A kérdôívek kitöltése és visszaküldése elektronikus úton történt. Eredmények: Szénanáthás tünetektől 305 fó szenved. Parlagfüszezonban, augusztus közepétől október végéig, 218 személy jelzett jellemzően szénanáthás panaszokat. E betegek $40 \%$-ának a tünetei több mint 5 éve fennállnak. A parlagfǘ-allergiások 18,3\%-a asthmás. Tüneteik enyhítésére $24 \%$ nem használt semmilyen gyógyszert vagy gyógyhatású készítményt, harmaduk még sohasem jelent meg allergiás panaszok miatt orvosi vizsgálaton. A parlagfü-allergiások az egyéb allergiásokkal összehasonlítva idősebbek, képzettebbek. A kérdőívet kitöltoók között kevésbé érvényesül a nói dominancia. Következtetések: A parlagfü-allergia okozta szénanátha és asthma ma Magyarországon 22\%-os előfordulást mutató népbetegség. Felismerésére, kezelésére és a parlagfú irtására további erőfeszítésekre van szükség. Orv. Hetil., 2016, 157(50), 1989-1993.
\end{abstract}

Kulcsszavak: parlagfü-allergia, epidemiológia, kérdőíves felmérés

\section{Characterisctics of ragweed allergy in Hungary}

Introduction: Although the prevalence of ragweed allergy in Europe is still low, it is increasing according to recent statistics. In contrast, in Hungary ragweed is the most common allergen with very high sensitisation in the general Hungarian population. Aim: We investigated the number and clinical characteristics of ragweed allergy in the Hungarian population, as the first comprehensive study to evaluate ragweed allergy in Hungary. Method: One thousand Hungarian adult subjects were screened with a questionnaire for ragweed allergy. People with ragweed allergy answered further specific questions about their disease history, symptoms and medication use. Results: 305 subjects reported allergy from which 218 patients had symptoms during ragweed pollination suggesting ragweed allergy. $40 \%$ of these had symptoms for more than 5 years. Asthma was reported in $18.3 \%$. Around $24 \%$ of these patients were undiagnosed; they did not take any medications or visited professionals because of their symptoms. Compared to the non-ragweed allergic patients, subjects with ragweed allergy were older and better educated, but the dominance of female gender was less prominent than in the non-ragweed group (all $\mathrm{p}<0.05$ ). Conclusions: Around $22 \%$ of the Hungarian population suffers from ragweed allergy. Studies should focus on eradication strategy and improvement of patient care.

Keywords: ragweed allergy, epidemiology, questionnaire-based data collection

Márk, Zs., Bikov, A., Gálffy, G. [Characterisctics of ragweed allergy in Hungary]. Orv. Hetil., 2016, 157(50), 19891993.

(Beérkezett: 2016. szeptember 15.; elfogadva: 2016. október 17.) 
Az utóbbi évtizedekben történt pollenfelmérések adatai szerint a parlagfü-szennyezettség Magyarországon a legnagyobb Európában $[1,2]$. Ez részben a parlagfü ( $A m b$ rosia artemisifolia) fejlődéséhez szükséges kedvező klimatikus viszonyokkal, részben a mezőgazdaság által múveletlenül hagyott területek nagyságával és nem kis részben a nem kielégítő parlagfưirtással függ össze. Bár a pollenterhelés nem teljesen azonos az ország különböző területein, parlagfümentes terület nincs ma Magyarországon. Korábban is történt néhány felmérés az allergiás szénanátha és ezen belül a parlagfü-allergia gyakoriságának meghatározására az országban, de ezek csak egy meghatározott területet és korosztályt elemeztek [3-8]. Jelen vizsgálat elsődleges célja a magyarországi parlagfüallergia gyakoriságának felmérése egy országos reprezentatív vizsgálat keretében. Másodlagos cél a parlagfú-allergiások tüneteinek, kivizsgálásának, gyógyszerfogyasztási szokásainak feltérképezése.

\section{Betegek és módszer}

A felmérést kérdőív segítségével végeztük. A kérdőív 4 bevezető kérdést tartalmazott, a parlagfüszezonban tüneteket jelző betegek további 14 kérdésre válaszoltak. A kérdések a jellegzetes szénanáthás tünetekre koncentráltak, mint az orrfolyás, az orrdugulás, a szemviszketés, a szemvörösség, a tüsszentés, valamint kitértek az esetleges asthmás tünetekre is, mint a mellkassípolás, a köhögés, a nehézlégzés. Mind a kérdőív, mind a felmérést végző személy a felsorolt tünetek augusztus-szeptemberi megjelenését hangsúlyozta.

Elektronikus úton kerestünk meg 1000 lakost a kérdőívvel. Minden megkérdezett válaszadása a kérdező segítségével és felügyeletével történt. Bizonytalan válaszadás esetén a kérdőívet ismételten kitöltötték. A kiválasztott személyek a Központi Statisztikai Hivatal adatbázisából kerültek ki. A megkérdezettek arányosan reprezentálják a 18 év feletti lakosság magyarországi településhálózatát. A mintába kerülő személyek összetételi aránya a legfontosabb társadalmi-demográfiai mutatók szerint (nemek, életkori csoportok, iskolai végzettség, lakóhelytípus) megfelelnek a teljes 18 éven felüli népesség összetételének. A minta kialakítása során a felmérésbe összesen 219 kistérséget vontunk be. Budapest kerületei, a megyei jogú, valamint a nagyvárosok is a minta részét képezték. Az adatfelvétel ideje a magyarországi parlagfüszezon utolsó heteiben történt: 2013. október utolsó és november első hetében. Az adatok statisztikai értékelését $\chi^{2}$-próbával végeztük.

\section{Eredmények}

Szénanáthás tünetektől a megkérdezettek 31\%-a, 305 fó szenved jellemzően az év valamelyik időszakában. E betegek demográfiai jellemzőit összehasonlítva a nem allergiás csoporttal, az 1. táblázat részletezi. A pozitív válaszadók mindössze 1\%-a észleli valamennyi tünetet.

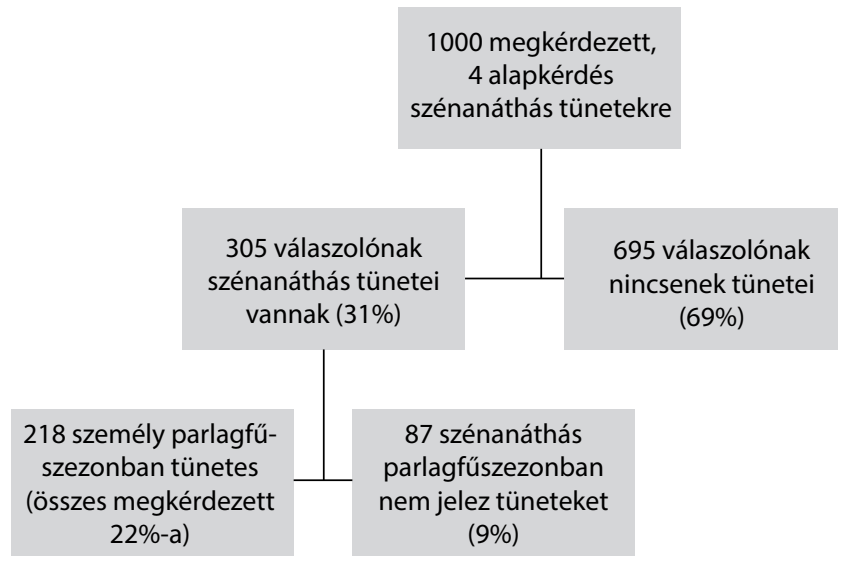

1. ábra

Nagyobb részük, 47\% csak egy jellemző tünetet említ. A leggyakoribb tünet az orrdugulás és a tüsszögéssel kísért vizes orrfolyás volt. A válaszadók 13\%-a tudott arról, hogy pollenallergiás, a tünetekkel élők 18\%-a nem gondolta, hogy az év azonos szakában visszatérő tünetei jellemzően lázas állapot nélküli allergiát jelenthetnek.

Az összes válaszadó 22\%-a, azaz 218 személy jelzett a parlagfüszezonban jellemzően szénanáthás panaszokat, azaz augusztus közepétől október végéig (1. ábra). A magyar lakosság 18 év feletti részére kivetítve ez

1. táblázat A szénanáthás betegek demográfiai jellemzőinek összehasonlítása a nem allergiás csoportéval

\begin{tabular}{|c|c|c|c|c|c|c|}
\hline & & \multicolumn{2}{|c|}{$\begin{array}{c}\text { Allergiás, } \\
\mathrm{n}=305\end{array}$} & \multicolumn{2}{|c|}{$\begin{array}{c}\text { Nem allergiás, } \\
n=695\end{array}$} & \multirow[t]{2}{*}{$\mathrm{p}$} \\
\hline & & fó & $\%$ & fó & $\%$ & \\
\hline \multirow[t]{5}{*}{ Életkor } & $18-29$ & 73 & 24 & 145 & 21 & \multirow[t]{5}{*}{0,37} \\
\hline & $30-39$ & 61 & 20 & 118 & 17 & \\
\hline & $40-49$ & 42 & 14 & 121 & 17 & \\
\hline & $50-59$ & 51 & 17 & 124 & 18 & \\
\hline & $>60$ & 78 & 25 & 187 & 27 & \\
\hline \multirow{2}{*}{$\mathrm{Nem}$} & Férfi & 114 & 37 & 351 & 51 & \multirow[t]{2}{*}{$<0,01$} \\
\hline & Nő & 191 & 63 & 344 & 49 & \\
\hline \multirow{2}{*}{$\begin{array}{l}\text { Családi } \\
\text { állapot }\end{array}$} & Egyedül él & 136 & 45 & 303 & 44 & \multirow[t]{2}{*}{0,73} \\
\hline & Társsal él & 169 & 55 & 392 & 56 & \\
\hline \multirow[t]{4}{*}{$\begin{array}{l}\text { Iskolai } \\
\text { végzettség }\end{array}$} & $\begin{array}{l}8 \text { általános vagy } \\
\text { kevesebb }\end{array}$ & 92 & 30 & 266 & 38 & \multirow[t]{4}{*}{0,01} \\
\hline & $\begin{array}{l}\text { Szakmunkás- } \\
\text { képző }\end{array}$ & 59 & 19 & 155 & 22 & \\
\hline & $\begin{array}{l}\text { Gimnázium, } \\
\text { szakközép- } \\
\text { iskola }\end{array}$ & 106 & 35 & 186 & 27 & \\
\hline & $\begin{array}{l}\text { Főiskola, } \\
\text { egyetem }\end{array}$ & 48 & 16 & 88 & 13 & \\
\hline \multirow{2}{*}{$\begin{array}{l}\text { Jövedelmi } \\
\text { viszonyok }\end{array}$} & Aktív kereső & 159 & 52 & 378 & 54 & \multirow[t]{2}{*}{0,51} \\
\hline & $\begin{array}{l}\text { Nem kereső } \\
\text { (nyugdíjas, } \\
\text { tanuló, } \\
\text { eltartott, } \\
\text { leszázalékolt, } \\
\text { munkanélküli, } \\
\text { gyes, gyed) }\end{array}$ & 146 & 48 & 317 & 46 & \\
\hline
\end{tabular}

A szignifikáns eltérések dőlt betüvel jelzettek. 

\begin{tabular}{l|l} 
2. táblázat & $\begin{array}{l}\text { A parlagfüre allergiás csoport összehasonlítása a parlagfüre nem } \\
\text { allergiás szénanáthásokkal }\end{array}$
\end{tabular}

\begin{tabular}{llccc}
\hline & & $\begin{array}{c}\text { Egyéb } \\
\text { allergia } \\
(\mathrm{n}=87)\end{array}$ & $\begin{array}{l}\text { Parlagfü- } \\
\text { allergia } \\
(\mathrm{n}=218)\end{array}$ & $\mathrm{p}$ \\
\hline Életkor & $18-29$ & 37 & 36 & $<0,01$ \\
& $30-39$ & 20 & 41 & \\
& $40-49$ & 14 & 28 & \\
& $50-59$ & 10 & 41 & \\
& $>60$ & 6 & 72 & 0,01 \\
\hline Nem & Férfi & 23 & 91 & 0,09 \\
& Nő & 64 & 127 & \\
\hline Családi & Egyedülálló & 46 & 91 & $<0,01$ \\
állapot & Házasságban vagy & 41 & 127 & \\
& életközösségben élő & & & \\
\hline Iskolai & Maximum általános iskola & 47 & 45 & \\
végzettség & Szakközépiskola & 3 & 56 & \\
& Gimnázium & 35 & 71 & \\
& Fóiskola vagy egyetem & 2 & 46 & \\
\hline Foglalkoz- & Dolgozó & 51 & 108 & \\
tatási & Munkanélküli & 36 & 110 & \\
státusz & & & & \\
\hline
\end{tabular}

A szignifikáns eltérések dölt betüvel jelzettek.

1725206 parlagfü-allergiást jelent a 8140697 lakosból. Az 1000 megkérdezett 5\%-a tudott asthmás betegségéról, s ez az adat nem különbözik a korábbról ismert magyarországi felmérésektől.

A parlagfü-allergiások demográfiai és gyógyszerfogyasztási jellemzőit kiegészítő, további 14 kérdésből álló kérdéscsoporttal vizsgáltuk.

A parlagfú-allergiások $42 \%$-a volt férfi, $58 \%$ nő. Korcsoport szerinti megoszlás: 16,6\% 18-29 éves, 18,8\% 30-39 éves, $12,8 \% 40-49$ éves, 18,8\% 50-59 éves és 33\% 60 éven felüli.

Iskolai végzettségüket tekintve a parlagfü-allergiások $58 \%$-a középiskolát, $21 \%$ főiskolát vagy egyetemet is végzett. A parlagfú-allergiások az egyéb allergiásokhoz hasonlítva képzettebbnek, idősebbnek bizonyultak (2. táblázat) és kevésbé érvényesül a női dominancia.

Az allergiás tünetek a válaszolók $40 \%$-ánál több mint 5 éve fennállnak, 60\%-uk 1-5 éve panaszos.

A parlagfüszezonban a válaszadók fele egyszerre több tünettel is rendelkezik: legjellemzőbb tüneteik az orrfolyás és tüsszentés, de a betegek 19\%-a nehézlégzésről, 7\%-a mellkassípolásról is beszámol (2. ábra). Ismert, orvosilag igazolt asthmája a parlagfú-allergiások 18,3\%ának van. Az asthmás tünetekról beszámolók több mint fele a 30-49 éves korcsoportból került ki, jellemzően az 5 évnél régebben allergiás csoportból. E betegek iskolai végzettsége alacsonyabbnak bizonyult, jelentős részük egyedülálló, nyugdíjas vagy inaktív. A parlagfü-allergiások 4\%-át kezelték már kórházban súlyos allergiás tünetek, asthmás roham miatt parlagfüszezonban. Ök jellemzően a 30-39 éves korcsoportból kerültek ki, és gyógyszereiket orvos írja fel.

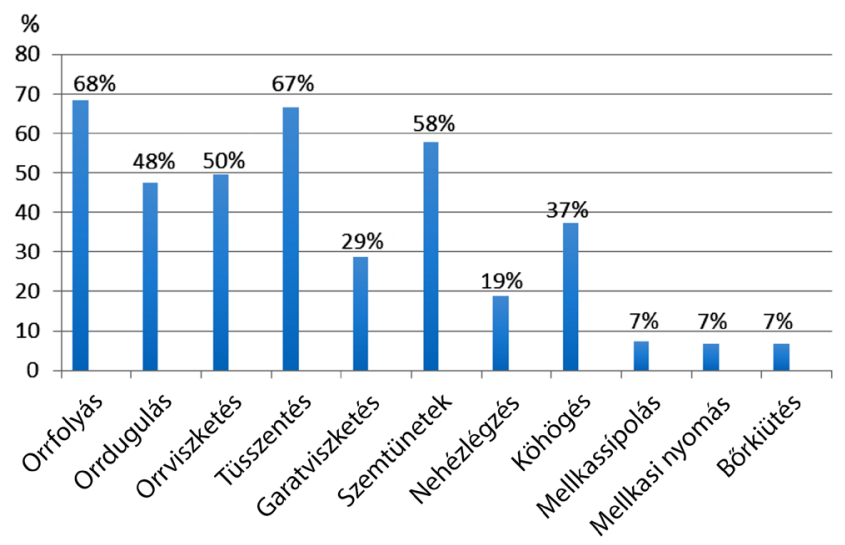

2. ábra |A parlagfü-allergiások jellemző tünetei, $\mathrm{n}=218$

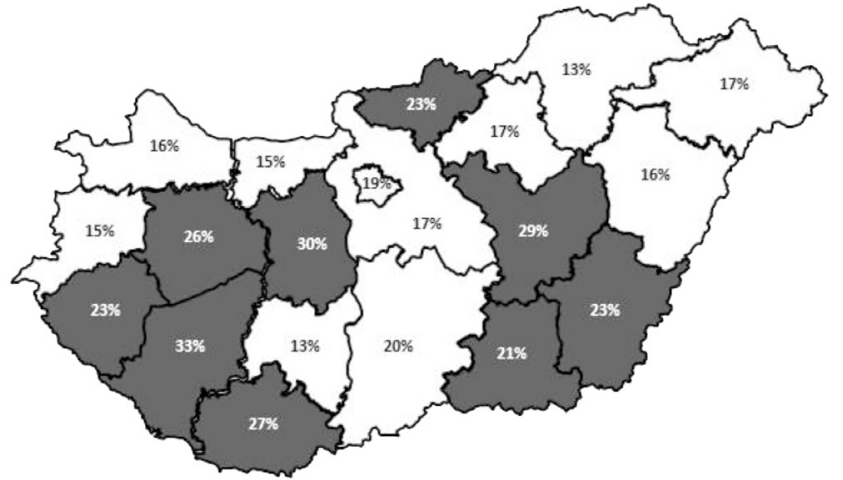

3. ábra $\begin{aligned} & \text { A parlagfü-allergiások megyék szerinti megoszlása (2013. októ- } \\ & \text { ber-november) }\end{aligned}$
A $20 \%$ feletti prevalenciát mutató megyék szürke színnel jelölve

A parlagfüullergiások megyék szerinti megoszlását mutatja a 3. ábra: a százalékos megoszlás kiszámolása úgy történt, hogy az adott területen megkérdezettek adott százaléka jelzett allergiás tüneteket a jellemző szezonban. A legtöbb allergiás Somogy és Fejér megyéből került ki (33\%, illetve 30\%).

Arra a kérdésre, hogy valaha végeztek-e bármilyen allergiatesztet, 38\% válaszolt úgy, hogy soha, 6\%-nak valamikor történt vérből allergiavizsgálat, 25\%-nak Prick-teszt, 31\%-nak pedig mindkettő. Az alacsony iskolázottságú, alacsony jövedelemmel rendelkező csoportoknál szignifikánsan magasabb azok aránya, akiknél egyik vizsgálatot sem végezték el. A magasabb jövedelemkategóriákba tartozóknál szignifikánsan alacsonyabb azok aránya, akiknél egyik vizsgálat sem történt meg.

Tüneteik enyhítésére 24\% nem használt semmilyen gyógyszert vagy gyógyhatású készítményt. A tünetesek csaknem fele $(45 \%)$ használt valamilyen orrsprayt, illetve orrcseppet, $44 \%$ pedig valamilyen antihisztamin-tartalmú tablettát. Inhalációs készítményt 17\% használt parlagfüszezonban, 10\% pedig valamilyen homeopátiás készítménnyel kezelte magát (4. ábra). Azok a betegek, akiknél a tünetek rövid ideje álltak fenn, jellemzően nem 
használtak semmit vagy legfeljebb homeopátiás készítményt.

A gyógyszert használók 48\%-ánál a gyógyszert orvos írta fel, 26\% a gyógyszereit részben orvossal íratta, 27\% pedig a gyógyszerész vagy ismerős javaslatára, vagy hirdetésben olvasott-látott gyógyszert vásárolt (tévéreklám, internetes oldal, gyógyszertári plakát, újsághirdetés).

A parlagfú-allergiások csupán fele látogatja legalább egyszer egy évben orvosát. Harmaduk még sohasem jelent meg allergia miatt orvosi vizsgálaton.

A fiatalokra (18-29 évesek) jellemző, hogy évente legalább egyszer felkeresik az orvost. Az alacsony végzettségüek, munkanélküliek körében a leggyakoribb, hogy még soha nem voltak orvosnál parlagfü-allergiájuk miatt. A háztartásbeli és egyéb inaktív csoportoknál figyelhető meg, hogy évente többször felkeresik az orvost.

A parlagfǘ-allergiások mintegy 29\%-ának más ismert allergiája is van.

A parlagfü-allergiások 30\%-a szenved valamilyen más krónikus betegségben is, ami gyakorisági sorrendben: magas vérnyomás, szív- és érrendszeri betegség, mozgásszervi betegség és cukorbetegség (64\%, 52\%, 42\%, 23\%). Refluxbetegségről 12\% tudott.

A parlagfü-allergiások vérrokonai között nagy százalékban fordult elő parlagfü-allergia $(35,3 \%)$ és egyéb allergia $(26,6 \%)$.

Az allergiások megoszlása a település jellegét tekintve a következőképpen alakult: 31\% lakik falun, 69\% városban.

\section{Megbeszélés}

A parlagfü (Ambrosia artemisiifolia) komoly elterjedése Európában a második világháború után kezdődött. A parlagfümagok a gabonaszállítmányokkal jutottak át az európai kikötőkbe, onnan pedig Olaszország, Franciaország, illetve Horvátország és a Dunántúl felé. Magyarországon az 1920-as években észlelték először az ország déli részén (akkori elnevezése: szerb fü). Míg 1968-ban Szegeden például egyetlen parlagfüpollent sem találtak, jelenleg a gyomnövény az egész országban

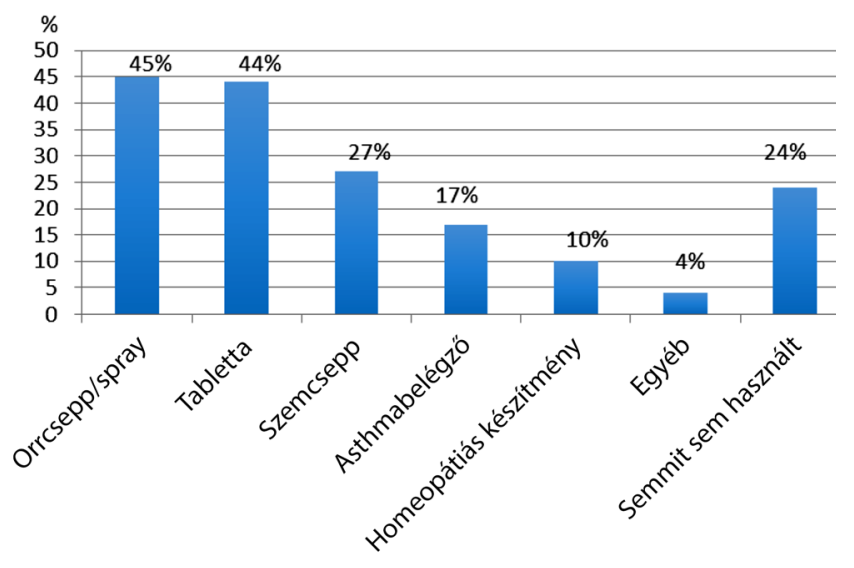

4. ábra $\mid$ A parlagfü-allergiások gyógyszerhasználati szokásai, $\mathrm{n}=218$ elterjedt. Európában a Kárpát-medence a legszennyezettebb régió, de jelentôs a parlagfü elterjedése a Rhône völgyében és Észak-Olaszországban is [9, 10].

Magyarországon a parlagfú jellemzően augusztus közepétől október végéig virágzik. A pollen okozta tünetek súlyossága függ a napi pollenkoncentráció nagyságától és a magas pollenkoncentrációjú napok számától. 100 db/ $\mathrm{m}^{3}$ feletti koncentráció már nagyon súlyos tüneteket okoz az arra érzékenyekben, a legmagasabb mért értékek ennek többszörösét teszik ki. (2010-ben Nyíregyházán például $1684 \mathrm{db} / \mathrm{m}^{3}$ parlagfüpollenszámot is mértek ÁNTSZ-jelentés.) Az ijesztően magas pollenszámok jól korrelálnak a parlagfü-allergiások számával (1. parlagfüszennyezettségi térkép).

A parlagfü-allergia elterjedésének becslésére készült páneurópai tanulmány (GA²LEN study) 13 európai országban 2026 résztvevő közremúködésével Prick-teszt végzésével vizsgálta a parlagfü-allergiások számát. Finnország kivételével a vizsgált egyedek közötti szenzitizáció 2,5\% feletti volt. A kiugróan legmagasabb szenzitizációt (60\% felett) Magyarországon találták [1]. A parlagfü okozta légzőszervi allergiás megbetegedések legjobban érintik Horvátországot $[11,12]$, Észak-Olaszországot $[13,14]$, Franciaország déli településeit [15]. Alacsonyabb a pollenterhelés, így viszonylag ritka a megbetegedés Németországban és Svájcban [15]. Az Egyesült Államokban 2005-2006-ban végzett, tünetekre koncentrált felmérés a parlagfǘ-allergiások számát az összes allergiás rhinitises 23,0-32,8\%-ának találta [16].

A korábban történt hazai felmérések elsősorban a szénanátha gyakoriságát vizsgálták. E vizsgálatok vagy egy meghatározott korosztályt céloztak meg, vagy egy bizonyos földrajzi területre lokalizálódtak. A különböző felmérések 3\% és 33,5\% közötti szénanátha-prevalenciát találtak. A felmérések egy része kérdőíves módszerrel készült, más része Prick-teszt vagy specifikus IgE-vizsgálattal [3-8].

Jelen vizsgálatunk elsődleges célja az országos elterjedés felmérése volt. A felmérés reprezentativitása biztosította, hogy a megkérdezettek területi, korosztályos, nemi és iskolai végzettségi aránya megfeleljen az országos átlagnak. A kérdéseket úgy állítottuk össze, hogy a parlagfúszezonban előforduló tünetes esetekre koncentráljanak. A számítógépes kontrollal feltett, személyes megkérdezés biztosította, hogy a válaszok valóban a kérdéses időszakban előforduló tüneteket tükrözzék. Nem zárható ki azonban, hogy a parlagfüszezonban jellemzően tünetes allergiások között néhány esetben más allergén, például gombaspóra vagy egyéb gyomnövény (fekete üröm) is szerepet játszhat a panaszok kialakulásában.

Luoma a kérdőíves felmérési módszer megbízhatóságát 85\%-osnak találta [17].

A jellemző időszakban szénanáthás és/vagy asthmás tüneteket tapasztaló betegek a megkérdezettek 22\%-át tették ki, ami egy igen jelentős betegszámot tükröz $(1,7$ millió embert érint). A betegség európai összehasonlításban is magas. A szénanáthás tüneteket jelzők 71\%-ának 
volt egy vagy több tünete a parlagfüszezonban. A legtöbb parlagfü-allergiás Somogy megye területén lakott, s ez jól tükrözi a Somogy megyei parlagfü-szennyezettséget.

A parlagfüu-allergiások 18,3\%-a ismerten asthmás volt. A parlagfüszezonban kórházi ellátásra szoruló asthmások száma (4\%) magasnak számít, hiszen az utóbbi évtizedekben hozzáférhető kiváló asthmagyógyszereknek köszönhetően csak a legsúlyosabb asthmások szorulnak ma már kórházi felvételre. E betegcsoport jellemzően rendszeresen felkeresi orvosát, és asthmagyógyszereit is orvos írja fel.

Magas a tüneteket mutató, de orvoshoz nem forduló betegek száma.

A vizsgálat eredménye szerint a magyar lakosság egyötöde szenved a parlagfü okozta tünetektől. Jelentős részük többféle gyógyhatású készítményt is használ. Fontos tennivaló az orvoshoz nem forduló betegek felismerése, a súlyos tünetek kezelése. Több a tennivaló a megelőzés terén, ami elsősorban a parlagfü irtását jelenti, de a betegek egy része talán tudná hasznosítani a magas pollenszámra figyelmeztető információkat is [18-21].

Anyagi támogatás: A vizsgálat az AstraZeneca, a Chiesi, a GSK gyógyszercégek és a Törökbálinti Tüdőgyógyintézet Alapítványának támogatásával készült.

Szerzői munkamegosztás: M. Zs.: A hipotézisek kidolgozása, a vizsgálat lefolytatása, az eredmények értékelése, statisztika elvégzése, a kézirat szövegezése. B. A.: Az eredmények értékelése, statisztika elvégzése, a kézirat szövegezése. G. G.: A hipotézisek kidolgozása, a vizsgálat lefolytatása, az eredmények értékelése. A cikk végleges változatát valamennyi szerző elolvasta és jóváhagyta.

Érdekeltségek: A szerzőknek nincsenek érdekeltségeik.

\section{Irodalom}

[1] Burbach, G. J., Heinzerling, L. M., Röhnelt, C., et al.: Ragweed sensitization in Europe - GA(2)LEN study suggests increasing prevalence. Allergy, 2009, 64(4), 664-665.

[2] D'Amato, G., Cecchi, L., Bonini, S., et al.: Allergenic pollen and pollen allergy in Europe. Allergy, 2007, 62(9), 976-990.

[3] Márk, Zs., Gálffy, G., Zolnai, E., et al.: Incidence rate of asthma bronchiale and rhinoconjunctivis allergica in adolescents. [Asthma bronchiale és rhinoconjunctivitis allergica előfordulási gyakorisága serdülókben.] Med. Thor., 1997, 50(2), 61-64. [Hungarian]

[4] Kadocsa, E., Juhász, M.: Change in the allergen spectrum of hay fever patients in the Southern Great Plains of Hungary (19901998). [A szénanáthás betegek allergénspektrumának változása a Dél-Alföldön (1990-1998).] Orv. Hetil., 2000, 141(29), 16171620. [Hungarian]

[5] Sóti, L., Endre, L.: Prevalence of the most common respiratory allergens generating positive Prick-reaction based on the examination of 2124 children suffering from respiratory allergy, between 1992-2000. [A pozitív Prick-reakciót kiváltó leggyakoribb légúti allergének gyakoriságának alakulása 1992 és 2000 között, 2124 légúti allergiában szenvedő gyermek vizsgálata alapján.] Orv. Hetil., 2005, 146(18), 833-837. [Hungarian]

[6] Sultész, M., Katona, G., Hirschberg, A., et al.: Prevalence and risk factors for allergic rhinitis in primary schoolchildren in Budapest. Int. J. Pediatr. Otorhinolaryngol., 2010, 74(5), 503-509.

[7] Mezei, G., Járainé, K. M., Medzihradszky, Z., et al.: Seasonal allergic rhinitis and pollen count (a 5 -year survey in Budapest). [Szezonális allergiás rhinitis és pollenszám (Ötéves felmérés Budapesten).] Orv. Hetil., 1995, 136(32), 1721-1724. [Hungarian]

[8] Szilasi, M., Gálffy, G., Fónay, K., et al.: A survey of the burden of allergic rhinitis in Hungary from a specialist's perspective. Multidiscip. Respir. Med., 2012, 7(1), 49.

[9] Makra, L., Juhász, M., Borsos, E., et al.: Meteorological variables connected with airborne ragweed pollen in Southern Hungary. Int. J. Biometeorol., 2004, 49(1), 37-47.

[10] Makra, L., Matyasovszky, I., Bálint, B.: Association of allergic asthma emergency room visits with the main biological and chemical air pollutants. Sci. Total Environ., 2012, 15(432), 288296.

[11] Cvitanović, S., Znaor, L., Kanceljak-Macan, B., et al.: Allergic rhinitis and asthma in southern Croatia: impact of sensitization to Ambrosia elatior. Croat. Med. J., 2007, 48(1), 68-75.

[12] Gajnik, D., Peternel, R., et al.: Methods of intervention in the control of ragweed spread (Ambrosia artemisiifolia L.) in the area of Zagreb County and the city of Zagreb. Coll. Antropol., 2009, 33(4), 1289-1294.

[13] Asero, R.: Ragweed allergy in northern Italy: are patterns of sensitization changing? Eur. Ann. Allergy Clin. Immunol., 2012, 44(4), 157-159.

[14] Tosi, A., Wüthrich, B., Bonini, M., et al.: Time lag between Ambrosia sensitisation and Ambrosia allergy: a 20-year study (19892008) in Legnano, northern Italy. Swiss Med. Wkly, 2011, 141, w13253.

[15] Ruëff, F., Przybilla, B., Walker, A., et al.: Sensitization to common ragweed in southern Bavaria: clinical and geographical risk factors in atopic patients. Int. Arch. Allergy Immunol., 2012, 159(1), 65-74.

[16] Salo, P. M., Calatroni, A., Gergen, P. J., et al.: Allergy-related outcomes in relation to serum IgE: results from the National Health and Nutrition Examination Survey 2005-2006. J. Allergy Clin. Immunol., 2011, 127(5), 1226-1235.e7.

[17] Luoma, R., Koivikko, A., Viander, M., et al.: Development of asthma, allergic rhinitis and atopic dermatitis by the age of five years. A prospective study of 543 newborns. Allergy, 1983, 38(5), 339-346.

[18] Bousquet, P., J., Chinn, S., Janson, C., et al.: Geographical variation in the prevalence of positive skin tests to environmental aeroallergens in the European Community Respiratory Health Survey I. Allergy, 2007, 62(3), 301-309.

[19] Smith, M., Cecchi, L., Skjoth, C. A., et al.: Common ragweed: a threat to environmental health in Europe. Environ. Int., 2013, 61, 115-126.

[20] Csépe, Z., Makra, L., Voukantsis, D., et al.: Predicting daily ragweed pollen concentrations using Computational Intelligence techniques over two heavily polluted areas in Europe. Sci. Total Environ., 2014, 476-477, 542-552.

[21] Makra, L., Matyasovszky, I., Thibaudon, M., et al.: Forecasting ragweed pollen characteristics with nonparametric regression methods over the most polluted areas in Europe. Int. J. Biometeorol., 2011, 55(3), 361-371.

(Márk Zsuzsa dr.,

Törökbálint, Munkácsy M. u. 70., 2045 e-mail: markzsuzsa@torokbalintkorhaz.hu, markzs@t-online.hu) 